\title{
Contribution of Products Domestic Bruto (GDP) Based on the Business Field on Poverty on Indonesia
}

\author{
Dr. Andi Sessu, M.Si \\ Faculty of Economics and Business \\ University of Muhammadiyah Prof. DR. HAMKA (UHAMKA) Jakarta, Indonesia
}

Received: April 8, 2018

Accepted: May 22, 2018

Published: May 30, 2018

doi:10.5296/wjbm.v4i1.13265

URL: https://doi.org/10.5296/wjbm.v4i1.13265

\begin{abstract}
The economic development in Indonesia from period to period until now is increasing because Indonesia is very rich with natural and human resources, only quality human resources need to improve their quality in order to be able to develop better economy in the future, however unemployment and poverty rate of Indonesia is still high compared to some other countries in the world, therefore it is necessary jointly between individual society, private and the government has maximum efforts to reduce unemployment and poverty in Indonesia, by increasing the growth of gross domestic product (GDP) contribution by business field can reduce poverty level in Indonesia. The result of multiple regression analysis shows that the contribution of GDP according to business field can decrease poverty level in Indonesia. This condition indicates that agriculture, forestry, fishery sector has a negative effect on poverty rate in Indonesia which means any decrease in agriculture, forestry, fishery by one unit affect the decrease of poverty level of 0.203 at constant $-7,70$, while the other three factors mining and quarrying, processing industry factor and trade factor have a positive effect on poverty level which means that every increase of one unit leads to a significant increase in poverty not yet able to reduce poverty level but has significant influence on all variables to poverty level in Indonesia. The results of multiple correlation coefficient analysis indicate that from each sector, agriculture, forestry, mining fishery, excavation, processing industry and trade are very strong together that is equal to $97,70 \%$, besides coefficient value of determination equal to $0,96 \%$ whereas the remaining $4 \%$ of the poverty rate is influenced by other factors
\end{abstract}

Keywords: Agriculture, Forestry, Fisheries, Mining, Quarrying, Processing, Trade, Poverty 


\section{Introduction}

Economic development in Indonesia from period to period is increasing because Indonesia is very rich with natural and human resources, only the quality of human resources need to improve quality in order to increase the independence and able to develop a better economy in the future, however, Indonesia's unemployment and poverty rate is still high compared to some other countries in the world, therefore it is necessary jointly between individual, private and governmental communities there is a maximum effort to reduce poverty and unemployment rates which one of the factors is growth population, by increasing the growth of the contribution of GDP according to the field of business can reduce the level of poverty in Indonesia. The national income accounting is one of the important innovations in measuring development indicators in the twentieth century.

The national income account shows the high level of national income of a country, as well as the contribution of each sector of economic activity to the level of national income concerned. In the national income account system are known some important terms, among GDP (Suparmoko \& Nurrochmat, 2005). One of the most important benchmarks in measuring a country's economic growth rate is to look at to GDP. GDP is a record of the amount of rupiah value of final goods and services produced by an economy within a country for a period of one year (Fatai et al., 2004). One of the main indicators in economic development is economic growth. Economic growth indicates the progress of economic activities in a certain year.

Economic growth can be defined as the growth of a country's a GDP. In an open economy, economic sector covers four sectors, i.e. corporate, household, government, and international. The use of production inputs by corporations will provide incomes to the sector in terms of salaries and wages, rent, interest, and profit. Household and economy will utilize its income for transactions, such as purchasing goods and services, produced by other sector , and saving the rest of the income in a financial institution (Suliswanto \& Kaluge, 2010) Indonesia's population growth rate is still at 1.49 percent, so in one year the population of Indonesia increases about 4 million people. This means that in July 2017 the population of Indonesia is more than 262 million people.

Central Bureau of Statistics (BPS) recorded from August 2016 to August 2017 the number of labour force increased $2.26 \%$ and revealed in 2017 there has been an increase in the number of unemployed in Indonesia, in August 2017 the number of unemployed rose to $7.04 \%$ million people of one cause of poverty. Also recorded the number of poor people in Indonesia in March 2017 reached 27.77 million, the percentage of the poor in September 2017 of 10.12 percent of the total population of Indonesia that there should be a maximum effort to lower it. With the development of GDP according to the field of business can open opportunities that can reduce unemployment and poverty in Indonesia (Central Bureau of Statistics, 2017)

\section{Literature Review}

\subsection{Global Economic Conditions and Indonesia}

The three fundamental factors have affected the process of economic globalization and are 
likely to continue driving it in the future. First, improvements in the goods transporting, and production factors or communicating of economically useful knowledge and technology. Second, the tastes of individuals and societies have generally, but not universally, favored taking advantage of the opportunities provided by declining costs of transportation and communication through increasing economic integration. Third, public policies have a positive influence on the direction of increasing economic integration (Mussa, 2000; Wuryandani, 2014). The dynamics of global conditions also affect the condition of Indonesia which will certainly affect the development of tourism and creative economy (Syamsudin et al., 2018). The global conditions that need to be of concern to the development of tourism and the creative economy are related to economic conditions, the development of the digital era, the conditions of connectivity between countries, as well as climatic and weather conditions. Post global economic crisis 2008-2009 the whole countries have entered a recovery (Chang et al., 2013)

The economic recovery marked improvement in world economic indicators, such as positive world GDP growth, world trade volume, and capital or investment flows in 2010. The world GDP in 2010 grew by $4.1 \%$, having previously experienced negative growth of $-2,3 \%$ in 2009 . World trade grew $12.8 \%$ in 2010, where in 2009 it grew negative $-11 \%$. Capital flows grew $5.4 \%$ in 2010, where in 2009 it only grew by $3.7 \%$. The economic recovery of the world cannot be separated from the efforts made in some countries such as monetary easing through interest rate reductions to encourage capital or investment flows, savings deposits, government stimulus packages, and other fiscal, banking, and real sector support policies (Schneider et al., 2010; Barbier, 2010; Keynes, 2017).

\subsection{Priority Scale on Agriculture and Rural People}

The agricultural sector will support development in other sectors. Various infrastructures to support the development of the agricultural sector are immediately prepared. For example, irrigation and transportation development, as well as farmers are trained on advanced agricultural methods so that they can increase production. Agricultural technology is introduced and disseminated to farmers through extension activities. Provision of supporting facilities, such as fertilizer, is secured by building fertilizer factories (Wijaya et al., 2018). The farmers are capitalized with the ease of obtaining bank credit. Marketing their crops is guaranteed by basic pricing and food procurement policies. This shows the consistency in the New Order era (Soharto era) in its efforts to increase rice production, and encourage its family to set an example. It turns out that the policy of in the New Order era that prioritized the development of agriculture sector, resulted in the achievement of self-sufficiency in rice, and the prevalence of the development results so that the less people who live below the poverty line (Axelsson \& Palacio, 2018). In 1984, for example Indonesia achieved self-sufficiency in rice. This is a turning point, since the 1970s, Indonesia is known as the largest rice importing country in the World (Purwaatmoko, 2018).

\subsection{Processing Industry}

The processing industry is part of the manufacturing industry that deals with manufacturing formulas and recipes, and is comparable to discrete manufacturing, which deals with discrete 
units, ingredient bills and assembling of components. The industrial sector is an important warring sector for the Indonesian economy Relevant (National Team for Achieving Poverty Reduction, 2011) Poverty reduction requires industrial sectors as well as labor intensive manufacturing (Saleh, 2018). The number of jobs provided by the service industry sector associated with all export activities that consider direct or indirect linkages, is greater than the total number of jobs created by all manufacturing exports (Kariyasa, 2001).

The industry occupies a central position in the economy of modern society and is an irreplaceable driving force for growth. For developing countries, the industry is essential to expanding the foundation of development and meeting ever-increasing needs. And while industrialized nations are said to be heading into an information-based, post-industrial era, this shift must be driven continuously by the wealth stream from industry. The investment has a positive impact on job creation (Raja \& Hasugian, 2018). Many of the main human needs are only biased by the goods and services provided by the industry. Food production requires more and more agricultural chemicals and machinery. In addition, industrial products become the material basis of living standards of today's society. So all nations need and deserve to aspire to an efficient industrial base to meet ever-changing needs.

\subsection{Mining and Quarrying}

Mining is an activity of extracting precious and economically valuable precious materials from the earth's crust, either mechanically or manually, on the surface of the earth, below the surface of the earth and below the surface of the water. The results include oil and gas, coal, iron sand, tin, nickel, bauxite, copper, gold and silver (Bloodworth et al., 2009; Cuevas et al., 2009). Excavation is an activity that includes taking all kinds of excavation. Minerals are chemical, mineral and all kinds of rocks that are natural sediments (excluding metals, coal, oil and gas and radioactive materials). These minerals are usually used as raw materials or helper materials for industrial sectors as well as construction. The results of excavation activities include mountain rocks, rocks, limestone, coral, gravel, marble, sand, silica sand, quartz sand, kaolin, clay and others. Crushing, smelting, refining, and all mining and quarry processing activities, however, are classified into industrial activities (Suseno, 2013).

\subsection{Poverty Level}

Poverty is a situation where there is an inability to meet basic needs such as food, clothing, shelter, education, and health (Ravallion, 2017). Poverty can be caused by the scarcity of basic needs fulfillment, or the difficulty of access to education and employment. Poverty is a problem of global. Some people understand this term subjective and comparative, while others see it in terms of moral and evaluative, and others understand it from a well-established scientific standpoint, and so on. (Suryawati, 2005; Jamison, 2018).

The government of President Susilo Bambang Yudoyono targets the poverty rate to reach 8-10 percent by the end of 2014. In achieving the target, the Government implements poverty reduction programs grouped into 3 clusters. The first cluster is a family-based poverty program, such as health, education and family planning programs $(\mathrm{PKH})$; the second cluster is a community-based poverty reduction program such as PNPM Mandiri; and the third 


\section{Macrothink}

cluster is a poverty alleviation program based on micro and small enterprises. The higher level of education of the head of the household will further reduce the chances of the household falling into poverty (Sumarto, 2012; Saragih, 2015; Winsemius et al., 2018).

\section{Methods}

The data in this study to be used are data of GDP Contribution by field of business that is agriculture forestry, fishery, mining, quarrying, processing industry and trade industries (wholesalers, retail, car and motor replication) and level of poverty, there is Central Bureau of Statistics (BPS) Jakarta and the offices of related agencies i.e. trade industries. The study was conducted in March 2018 until June 2018. This research wishes to suggest that by increasing the growth or development of agriculture, forestry, fishery, mining and quarrying, processing and trade industries can reduce poverty level in Indonesia, population of all data in Indonesia related to these variables.

Therefore, the researcher determines the research population of all national level data related to the research problem at the Indonesian BPS Office and to the related institution. Due to the limited ability of researcher in terms of time and energy, in this study, the research sample is limited to the last 15 years data, starting from 2002 to 2016. Design of the analysis that will be used include descriptive statistics to provide general overview on research and statistical infrensial to test the hypothesis of the frequency distribution table, histogram and polygon frequency, mean, virians, median, mode, standard deviation, work, poverty level formula, multiple linear regression

Multiple regression models:

$$
Y=a_{0}+a_{1} x_{1}+a_{2} x_{2}+a_{3} x_{3}+a_{4} x_{4}+e
$$

Where:

$$
\begin{aligned}
\mathrm{Y} & =\text { Poverty levels } \\
\mathrm{a}_{0} & =\text { constant } \\
\mathrm{a}_{1}, \mathrm{a}_{2}, \mathrm{a}_{3}, \mathrm{a}_{4} & =\text { regression coefficient } \\
\mathrm{X}_{1} & =\text { Agriculture, forestry and fishery } \\
\mathrm{X}_{2} & =\text { Mining and quarrying } \\
\mathrm{X}_{3} & =\text { Processing industry } \\
\mathrm{X}_{4} & =\text { Trade industries (wholesalers, retail, car and motor replication) } \\
\mathrm{e} & =\text { error }
\end{aligned}
$$

Poverty line formula:

$$
P_{\alpha}=\frac{1}{n} \sum_{i=1}^{q}\left(\frac{z-y_{i}}{z}\right)^{\alpha}
$$

$$
\begin{aligned}
\alpha= & 0 \\
z= & \text { Poverty line } \\
y_{\tilde{i}}= & \text { average monthly per capita expenditure of population below the poverty line }(\mathrm{I}= \\
& 1,2,3, \ldots \ldots, \mathrm{q}), \mathrm{yi}<\mathrm{z}
\end{aligned}
$$


$\mathrm{q}=$ the number of people below the poverty line

$\mathrm{n}=$ population

\section{Results}

GDP contribution data by business sector data of increasing of agriculture, forestry, and fisheries $\left(\mathrm{X}_{1}\right)$, mining and quarrying $\left(\mathrm{X}_{2}\right)$, processing industry $\left(\mathrm{X}_{3}\right)$, trade (wholesalers, retail, car and motorcycle repairs) $\left(\mathrm{X}_{4}\right)$, poverty rate $(\mathrm{Y})$ in Indonesia as shown in the table below:

Table 1. The growth of agricultural, forestry and fisheries $\left(\mathrm{X}_{1}\right)$, mining and quarrying $\left(\mathrm{X}_{2}\right)$, manufacturing industry $\left(\mathrm{X}_{3}\right)$, trade $\left(\mathrm{X}_{4}\right)$ and poverty levels $(\mathrm{Y})$

\begin{tabular}{|c|c|c|c|c|c|}
\hline Years & $\mathrm{X}_{1}$ & $\mathrm{X}_{2}$ & $\mathrm{X}_{3}$ & $\mathrm{X}_{4}$ & $\mathrm{Y}$ \\
\hline 2002 & 16,04 & 8,64 & 29,73 & 16,87 & 18,20 \\
\hline 2003 & 15,93 & 8,28 & 28,83 & 16,55 & 17,42 \\
\hline 2004 & 14,30 & 8,90 & 28,10 & 16,10 & 16,66 \\
\hline 2005 & 13,10 & 11,10 & 27,40 & 15,60 & 15,97 \\
\hline 2006 & 13,00 & 11,00 & 27,50 & 15,00 & 17,75 \\
\hline 2007 & 13,80 & 11,10 & 27,00 & 14,90 & 16,58 \\
\hline 2008 & 14,50 & 10,90 & 27,80 & 14,00 & 15,40 \\
\hline 2009 & 15,30 & 10,60 & 26,40 & 13,30 & 14,20 \\
\hline 2010 & 13,93 & 10,46 & 22,04 & 13,46 & 13,30 \\
\hline 2011 & 13,53 & 11,81 & 21,76 & 13,61 & 12,50 \\
\hline 2012 & 13,37 & 11,61 & 21,45 & 13,21 & 11,70 \\
\hline 2013 & 13,36 & 11,01 & 21,03 & 13,21 & 11,50 \\
\hline 2014 & 13,34 & 9,83 & 21,08 & 13,48 & 11,00 \\
\hline 2015 & 13,49 & 7,65 & 20,97 & 13,31 & 11,10 \\
\hline 2016 & 13,45 & 7,21 & 20,57 & 13,19 & 10,90 \\
\hline
\end{tabular}

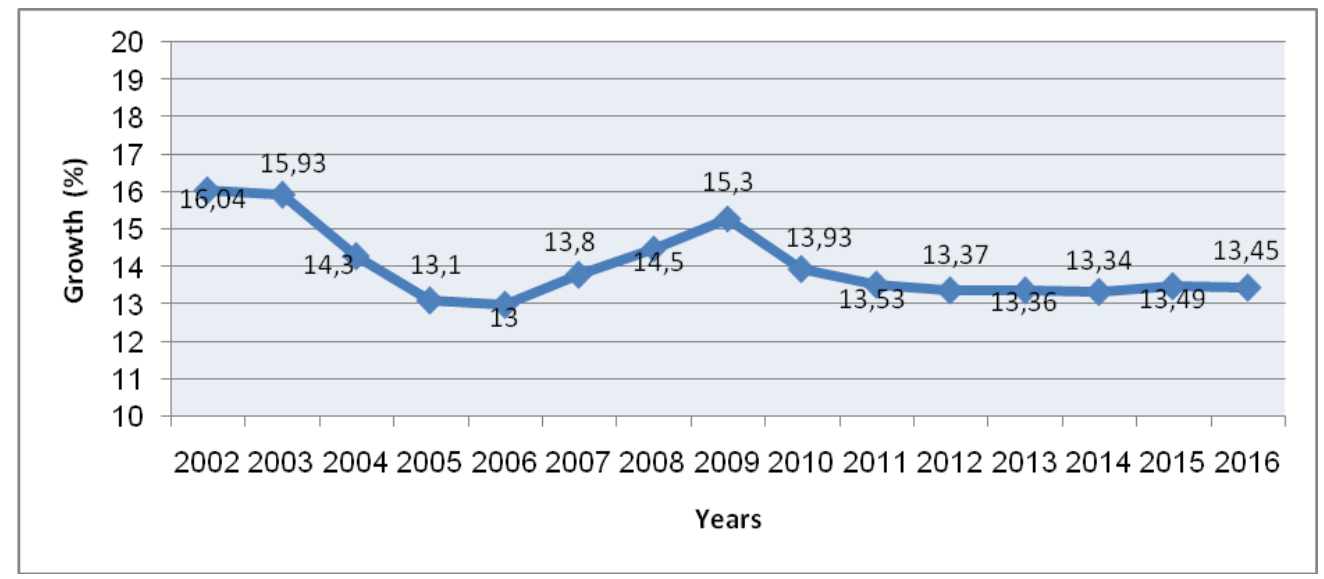

Figure 1. The growth of agricultural, forestry and fisheries (Percentage) 


\section{Macrothink}

World Journal of Business and Management

ISSN 2377-4622

2018, Vol. 4, No. 1

From data on the agricultural, Forestry, fisheries over the past 15 years from from 2002 to 2016, the data show corresponding on the graph from 2002 to 2006 decline, after 2006 the higher growth until 2010 and 2011 until 2016 its growth is flat.

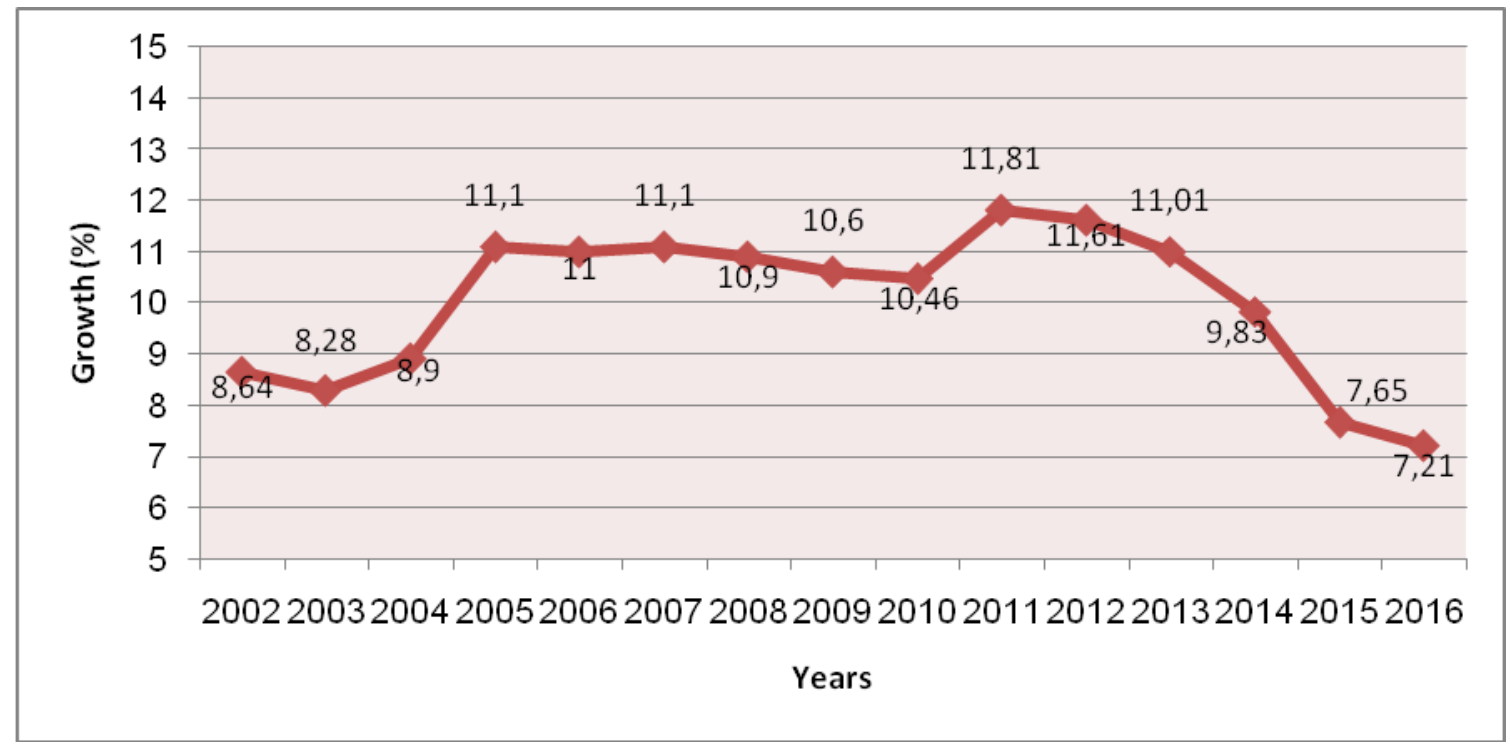

Figure 2.The growth of mining and quarrying (Percentage)

The growth from the data of mining and quarrying during the last 15 years from 2002 to 2016, the data show that according to the graph from 2002 to 2011 the growth rate is higher than that of 2003 which is $8.28 \%, 2015$ and 2016 decreased (lower) from 2003 at $8.28 \%$.

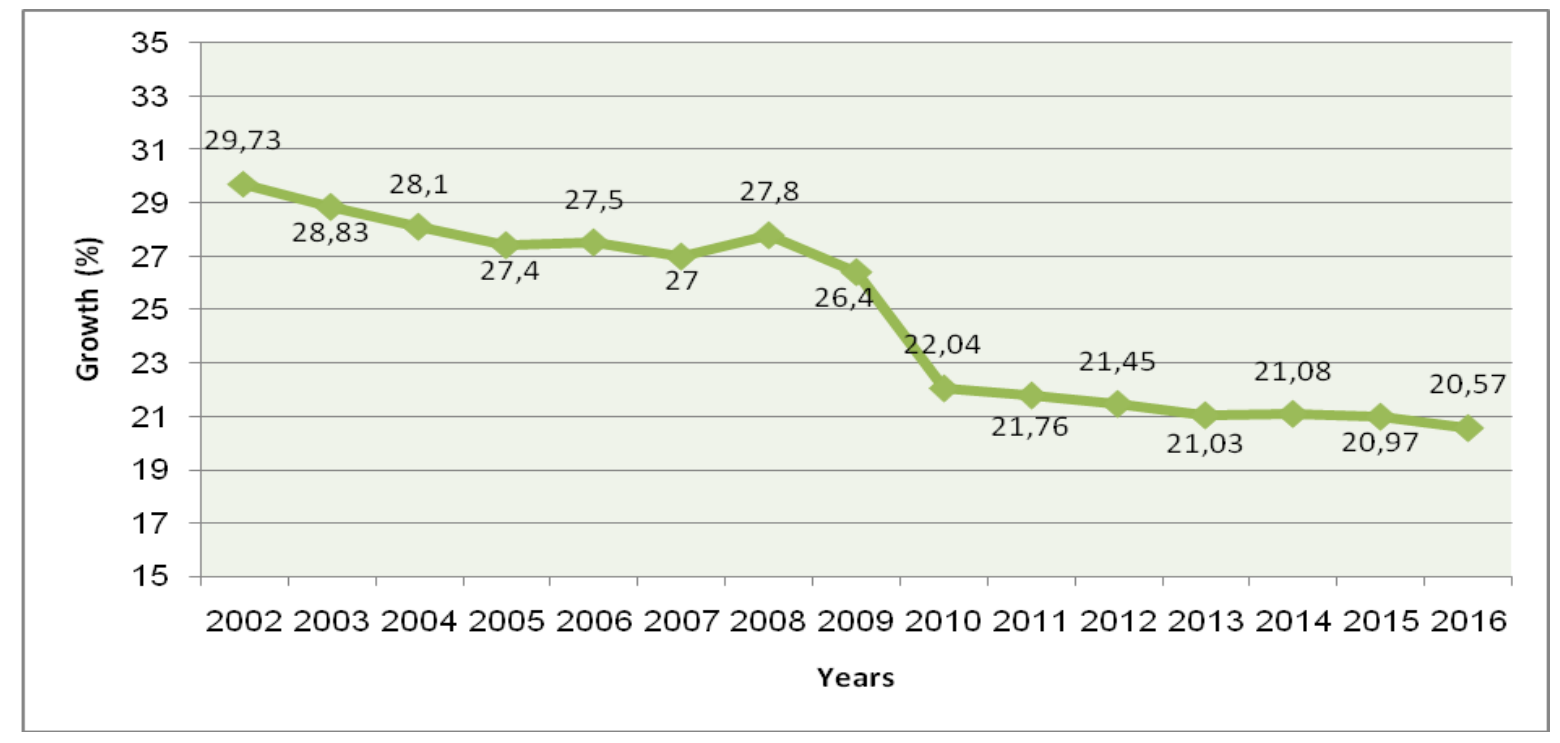

Figure 3.The growth of processing industry (Percentage) 


\section{Ml Macrothink}

World Journal of Business and Management

ISSN 2377-4622

2018, Vol. 4, No. 1

The data of processing industry's growth over the last 15 years from 2002 to 2016, according to the chart data showed from 2002 to 2016 the industrial growth has declined until 2016.

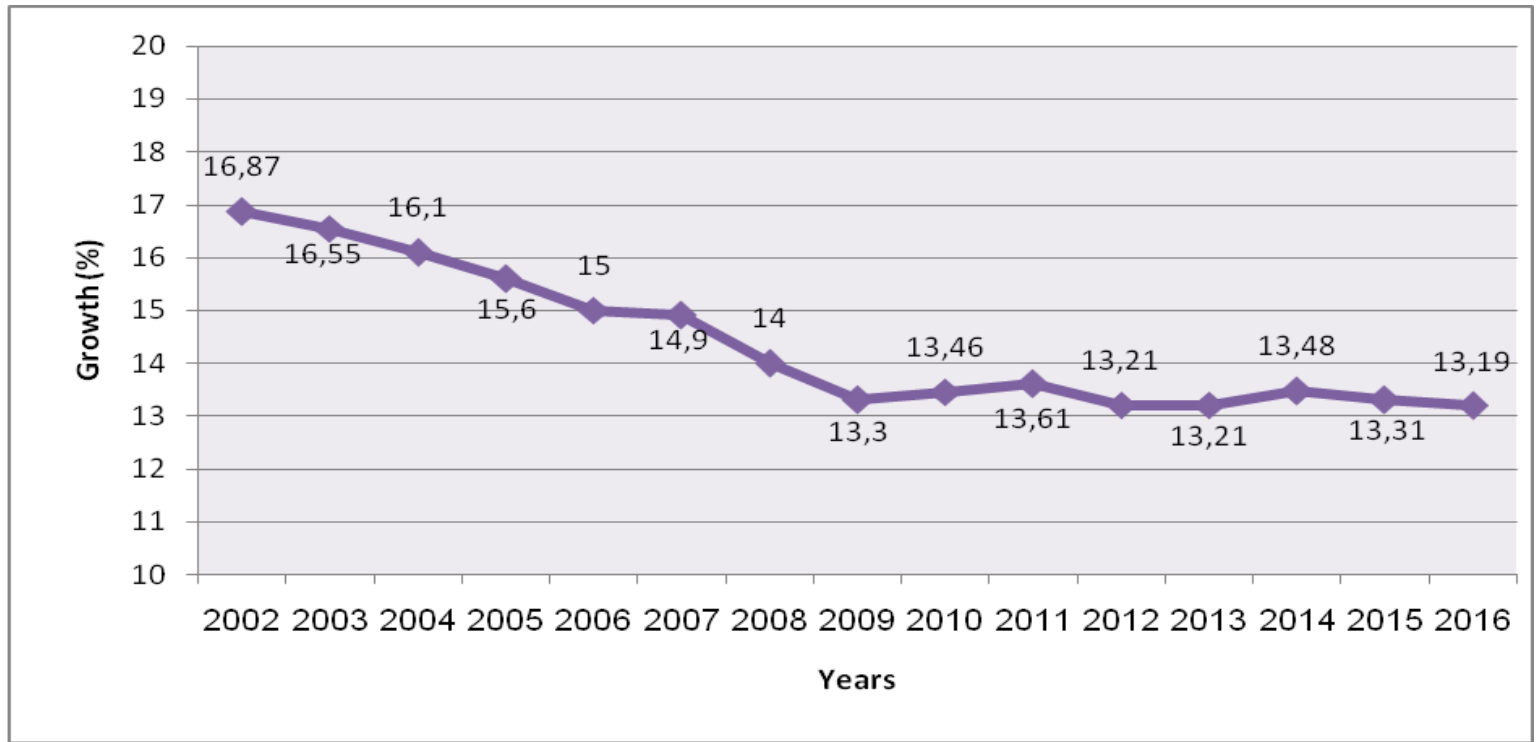

Figure 4. The growth of trade industries (wholesalers, retail, car and motor replication)

From the data of trade industries (wholesalers, retail, car and motor replication) for the last 15 years from 2002 to 2016, the data show fit on the graph of from 2002 to 2016 declined until 2016.

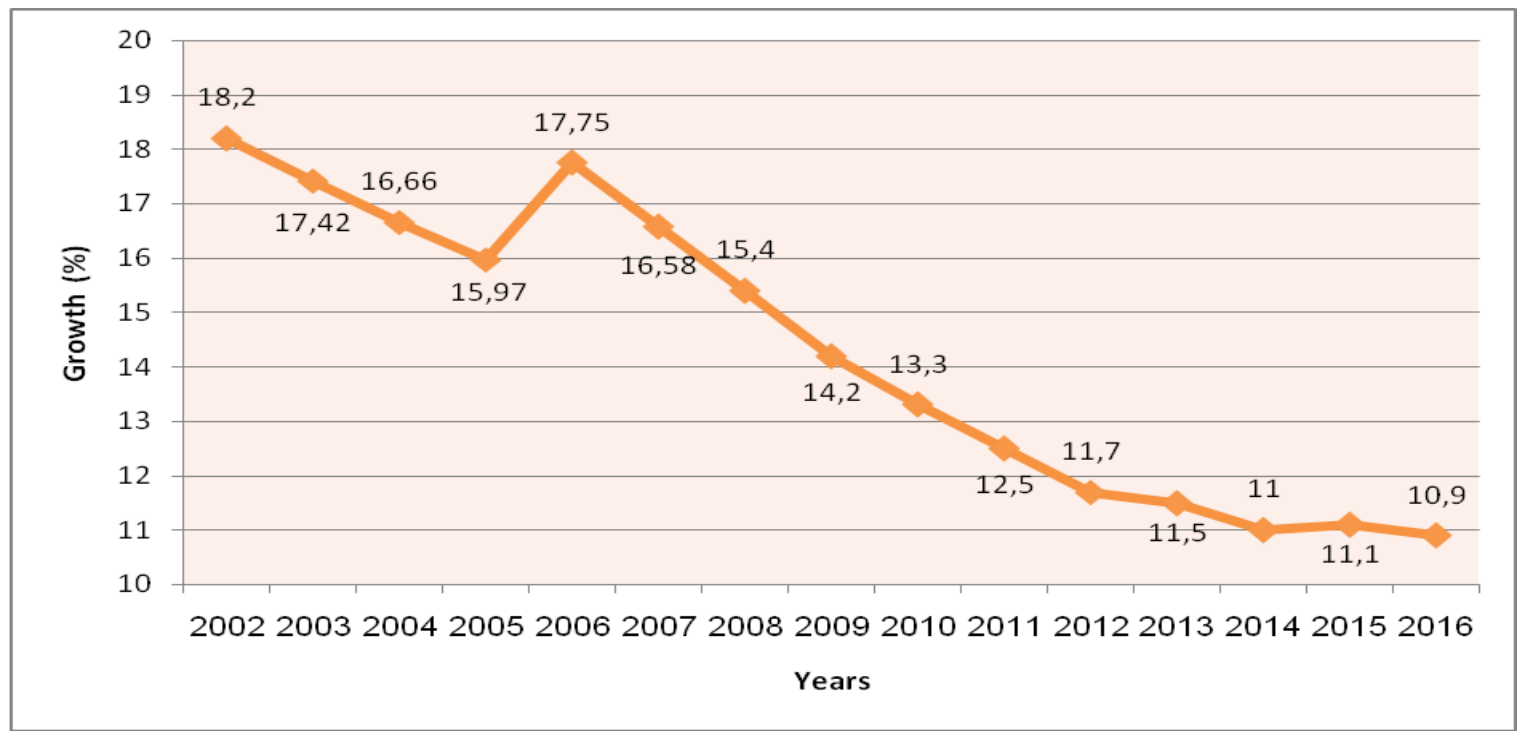

Figure 5. The growth of poverty level

From the data of poverty rate growth over the last 15 years from 2002 to 2016, the data show that according to the graph from 2002 to 2016 decreased as expected by the community and government. 


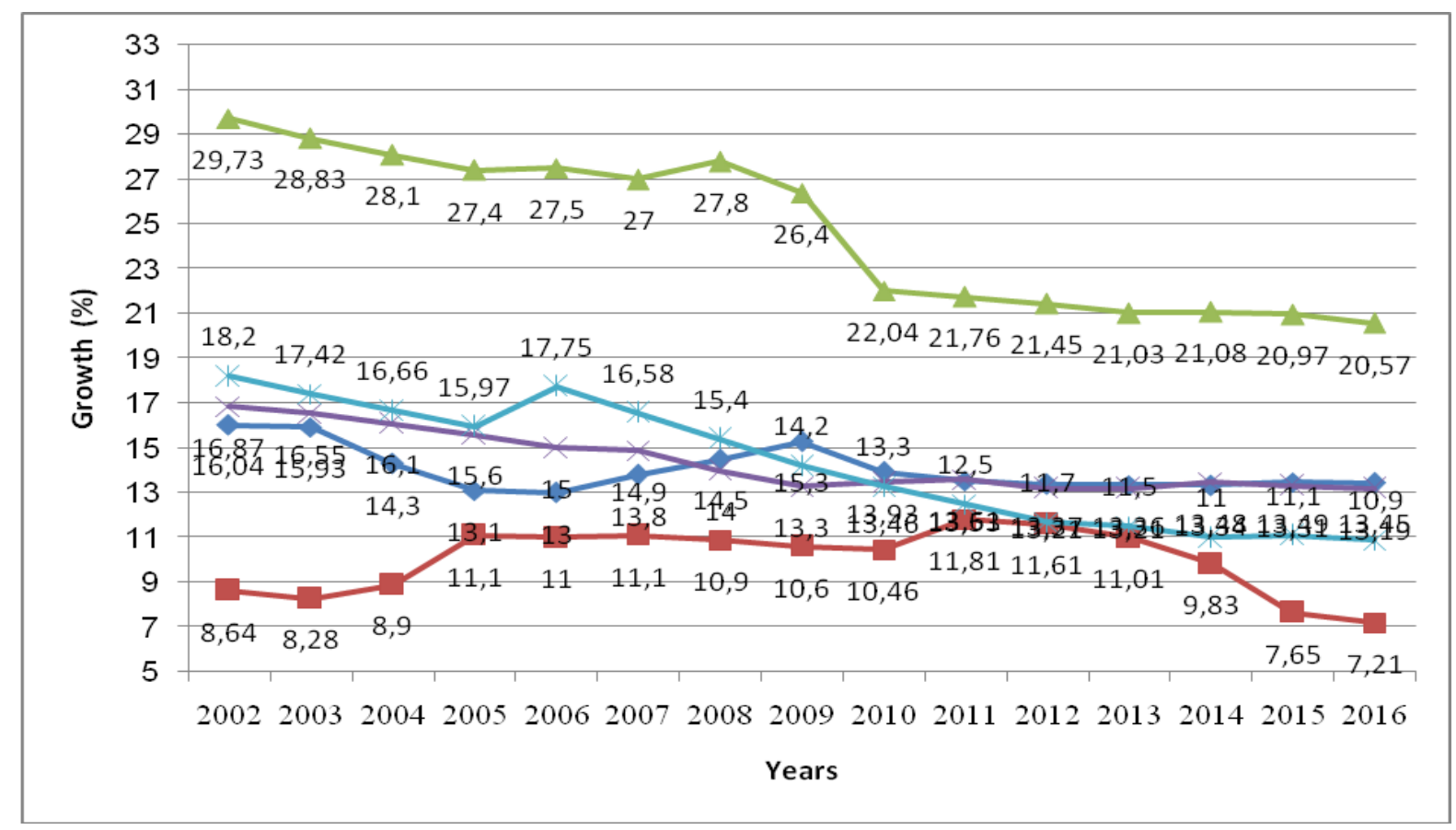

Figure 6. The growth of compilation variables

From the results of multiple regression analysis obtained $Y=-7,70-0,203 X_{1}+0,155 X_{2}+$ $0,588 X_{3}+0,605 X_{4}$, shows that the growth of GDP contribution according to business field can decrease poverty level in Indonesia. From the regression shows that agriculture, forestry, fisheries negatively affect the level of poverty in Indonesia which means that every increase of agriculture, Forestry and fishery for one unit (score 1) affects poverty reduction of 0.203 at -7.70 constant, while the three variables (processing industry, trade industries mining and quarrying), has a positive effect which means that every increase for one unit (score 1) of the three variables also experienced an increase of poverty level which means not able to decrease poverty level and yet still have significant influence all variable to poverty level in Indonesia.

The results of the analysis of multiple correlation coefficient $r=0.977$, shows the influence to four variables of agriculture / forestry / fishery mining / quarrying, processing industry and trade together very strong and coefficient of determination together four variables in $\mathrm{R}=$ 0.955 shows the percentage of contribution a joint influence of $96 \%$ means that only $0.04 \%$ contributes to the influence of other variables on poverty levels in Indonesia.

\section{Conclusion}

From the results of data analysis shows that the growth of contribution of GDP by business field can reduce poverty level in Indonesia. From the regression shows that agriculture, forestry, fishery have a negative effect on poverty rate in Indonesia which means that every increase of agriculture, forestry, and fishery also decrease poverty level in Indonesia that is equal to 0,203 at constant $-7,70$. Factors that influence them, because the absorption of labor in Agriculture, forestry and fisheries all levels of education can be absorbed which can 
automatically reduce the level of poverty. While the three ((processing industry, trade industries mining and quarrying) have a positive effect which means that every increase of the growth of the three variables has not been able to influence the decreasing of poverty level in Indonesia.

Because there are several factors that influence among them import is still high, low export, education and skill still low yet support the improvement of performance both quality and quantity, so that there are limitations to absorb labor which consequently to the level of poverty is still high in Indonesia. Results of multiple correlation coefficient analysis obtained $\mathrm{r}=0.977$ shows the effect to four variables of agriculture, forestry, fishery, mining and quarrying, processing industry and trade together to very strong poverty rate and coefficient of determination together four variables in $\mathrm{R}=0.955$ shows the percentage of influence contribution together equal to $96 \%$ mean only $0,04 \%$ contribution of influence of other variable to poverty level in Indonesia. This research suggest the need of government policy to suppress import, increase export especially commodity (goods) that can in Indonesia production, tax policy, government support policy to industrial development, existence of effort of government program in improving human resources quality of education formal and non-formal education that can support the growth activities of GDP contribution according to the field of business, so that the bias affects the decrease of poverty level in Indonesia.

\section{References}

Adams, K. M. (2018). Tourism, economy, and society. Routledge Handbook of Contemporary Indonesia.

Axelsson, T., \& Palacio, A. (2018). Transforming Indonesia: Structural Change from a Regional Perspective, 1968-2010. In Agricultural Development in the World Periphery, pp. 281-305. Palgrave Macmillan, Cham. https://doi.org/10.1007/978-3-319-66020-2_11

Barbier, E. B. (2010). A global green new deal: Rethinking the economic recovery. Cambridge University Press. https://doi.org/10.1017/CBO9780511844607

Bloodworth, A. J., Scott, P. W., \& McEvoy, F. M. (2009). Digging the backyard: Mining and quarrying in the UK and their impact on future land use. Land Use Policy, 26, S317-S325. https://doi.org/10.1016/j.landusepol.2009.08.022

Central Bureau of Statistics. (2017). Indonesia 2003-2016. Jakarta.

Chang, S. S., Stuckler, D., Yip, P., \& Gunnell, D. (2013). Impact of 2008 global economic crisis on suicide: time trend study in 54 countries. Bmj, 347, f5239. https://doi.org/10.1136/bmj.f5239

Cuevas, S., Rosario, A., Barcenas, M. L., \& Christian, M. (2009). Informal employment in Indonesia.

Fatai, K., Oxley, L., \& Scrimgeour, F. G. (2004). Modeling the causal relationship between energy consumption and GDP in New Zealand, Australia, India, Indonesia, The Philippines and Thailand. Mathematics and Computers in Simulation, 64(3-4), 431-445. 
https://doi.org/10.1016/S0378-4754(03)00109-5

Jamison, D. T. (2018). Disease Control Priorities: improving health and reducing poverty. The Lancet, 391(10125), e11-e14. https://doi.org/10.1016/S0140-6736(15)60097-6

Keynes, J. M. (2017). The economic consequences of the peace. Routledge.

King, T. H. L., \& Hasugian, P. R. T. (2018). Gross Regional Domestic Influence Product (PDRB), Total Population, And Capital Expenditures on Pad (Regional Generated Revenue) (A Case Study In District And Towns In North Sumatra Province). Advances in Social Sciences Research Journal, 5(1).

Mussa, M. (2000). Factors driving global economic integration. Global Economic Integration: Opportunities and Challenges, 9-55.

Purwaatmoko, S. (2018). Obstacles to Achieving Food Security: The Failure of Rice Sector Policy and Its Impact on Peasant Deprivation in the Era of Political Reform in Indonesia. In Sustainable Future for Human Security (pp. 213-231). Springer, Singapore. https://doi.org/10.1007/978-981-10-5430-3_17

Ravallion, M. (2017). Poverty comparisons. Routledge.

Saragih, J. P. (2015). Poverty Alleviation Policy in Yogyakarta Special Region. Journal of Economics and Public Policy, 6(1), 45-59.

Schneider, F., Buehn, A., \& Montenegro, C. E. (2010). New estimates for the shadow economies all over the world. International Economic Journal, 24(4), 443-461. https://doi.org/10.1080/10168737.2010.525974

Suliswanto, M. S. W., \& Kaluge, D. (2010). Globalization and gross domestic product construction in Asean. Economic Journal of Emerging Markets, 2(2), 155-167.

Sumarto, S. (2012, August). Reducing leakages: Key lessons and challenges from policy-making in Indonesia. In Impact and Policy Conference: Evidence in Governance. Financial Inclusion and Entrepreneurship, 31.

Suparmoko, M., \& Nurrochmat, D. R. (2005). Urgency of Green Sector GRDP Implementation. Forestry Planning Agency, Jakarta.

Suryawati, C. (2005). Understanding poverty is multidimensional. Journal of Health Services Management, 8(03).

Suseno, T. (2013). Contribution of Coal Mining Investment to Gross Regional Domestic Product of West Papua Province. Journal of Mineral and Coal Technology, 9(3), 118-134.

Syamsudin, M., Hakim, A., Harahap, N., \& Afandhi, A. (2018). Regulation Implementation of Kelam Hill Nature Tourist Park to Sustainable Environment and Tourism (A Case Study in Kelam Permai Sub-Regency Sintang West Kalimantan). Resources and Environment, 8(2), 31-37.

Wijaya, A., Glasbergen, P., Leroy, P., \& Darmastuti, A. (2018). Governance challenges of 


\section{Macrothink}

World Journal of Business and Management

ISSN 2377-4622

2018, Vol. 4, No. 1

cocoa partnership projects in Indonesia: seeking synergy in multi-stakeholder arrangements for sustainable agriculture. Environment, Development and Sustainability, 20(1), 129-153. https://doi.org/10.1007/s10668-016-9874-8

Winsemius, H. C., Jongman, B., Veldkamp, T. I., Hallegatte, S., Bangalore, M., \& Ward, P. J. (2018). Disaster risk, climate change, and poverty: assessing the global exposure of poor people to floods and droughts. Environment and Development Economics, 1-21. https://doi.org/10.1017/S1355770X17000444

Wuryandani, D. (2014). Opportunities and Challenges of Indonesian Human Resources Towards the Era of ASEAN Economic Community. Brief Info on Economics and Public Policy, 6.

\section{Copyright Disclaimer}

Copyright for this article is retained by the author(s), with first publication rights granted to the journal.

This is an open-access article distributed under the terms and conditions of the Creative Commons Attribution license (http://creativecommons.org/licenses/by/3.0/). 